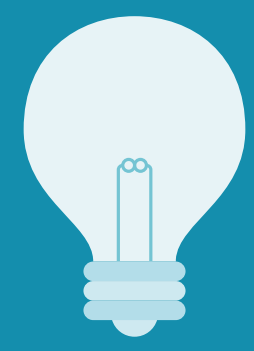

THE STORIES
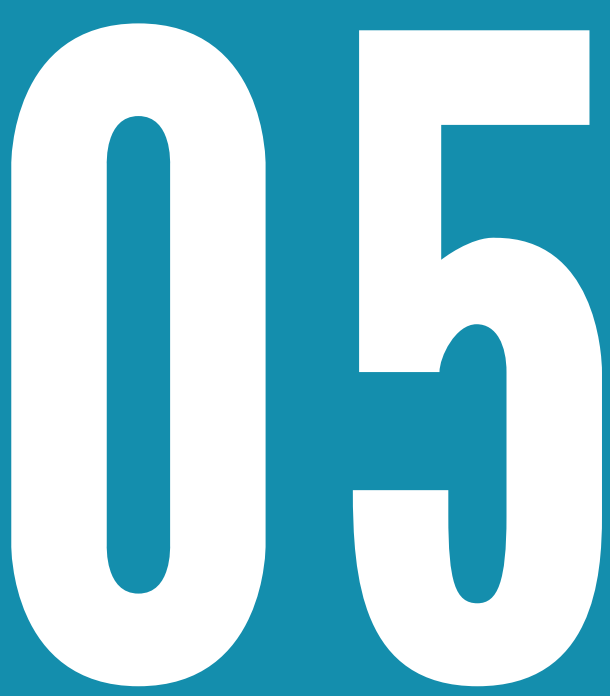


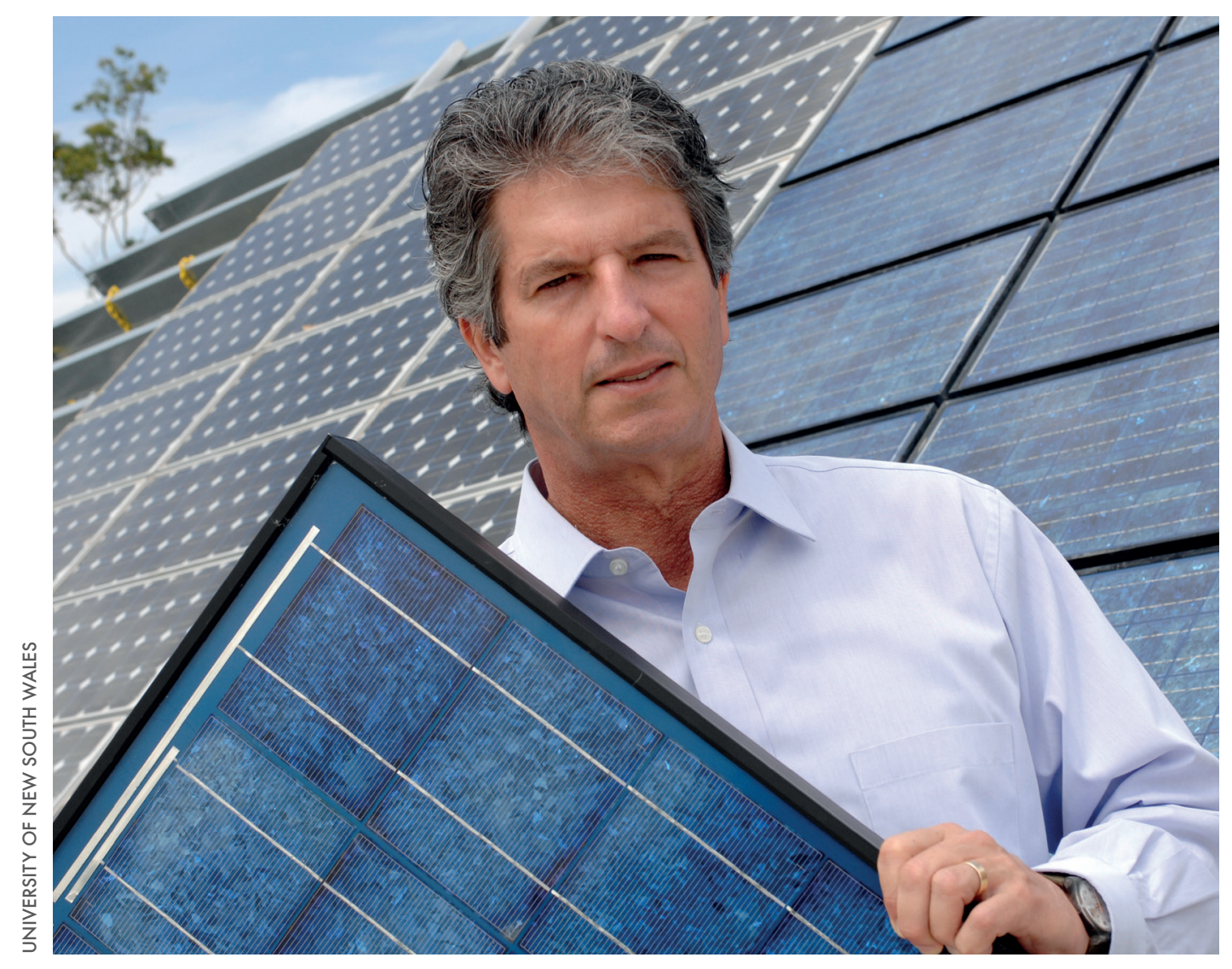

\section{Martin Green}

'The Father Of Photovoltaics' 
This century we've already experienced 15 of the 16 hottest years on record, with 2011-2015 being the warmest five-year period in recorded history. In March 2016, the US-based National Oceanic and Atmospheric Administration announced global temperatures had smashed records for the 10th straight month, and while the run of broken records is worrying enough, it is the margin by which those records were broken that is of most concern. February, for example, jumped 2.18 degrees above the previous average, which is an unprecedented spike considering records are usually only broken by hundredths or tenths of a degree, and leading meteorologists attribute at least half of this spike to global warming.

While climate scientists, politicians and industry struggle to reach consensus on the best way to respond to global warming, some fear this accelerated rate of heating could be an indicator we've done too little, too late. What almost everyone does agree upon, however, is that global warming is a reality, that the primary driver of this unprecedented level of climate change is human activity, and that urgent societal response is essential. In other words, reducing emissions and finding new ways to meet our power needs is crucial in order to save ourselves from a likely global environmental catastrophe.

Every hour the sun beams more than enough energy to Earth to satisfy global needs for an entire year, yet it currently generates only about 1 per cent of our electricity. So, when the man who has led the world in the race to capture and covert that energy into electricity for the past 30 years tells you that conferences were a constant and critical motivator that pushed him towards his achievements, it's important to ask why.

Professor Martin Green (OAM) has received countless awards for his lifetime of work developing and improving the efficiency of solar cells, including the 2002 Right Livelihood Award (Alternative Nobel Prize), the 2004 World Technology Award for Energy, and the 2016 Australian Academy of Science's prestigious Ian Wark Medal and Lecture. He spearheads an extensive research team at the University of NSW (UNSW) that is set to revolutionise the global energy industry, and happily admits conferences have played a very important part in that team's ongoing success. 
"I think [conferences] have been critical because they've pushed our research along.

"Conferences were the opportunity to show off your new results ... so they were always a big motivator for everyone to try to get the best results in before a conference. Having a conference was like having a focal point for what you were doing in your research. Often there'd be a jump in your achievements the month or two before a conference because everyone strove to get the best results [to be able to] report on them at the conference."

A graduate of the University of Queensland, Green started his career in micro-electronics, but began losing interest in what he then saw as being mainly development of consumer entertainment products (TV/radio components etc.). Driven by an urge to do something more meaningful and challenging, he started looking into the (then) fledgling area of photovoltaics (cells which can convert sunlight directly into energy). When the 1973 oil embargo raised questions and concerns in the US about our social and economic dependence on this expensive and limited resource, interest and support for alternative energy research such as Green's increased. He and his colleagues at UNSW fabricated their first solar cell there in 1975 and the following year organised a trip to the IEEE Photovoltaic Specialists Conference being held in the US to present on their results.

They saw the trip as an opportunity to learn everything they could about the latest developments in their field, and prepared a hectic itinerary for the weeks prior to and following the conference. They tried to visit two research groups or start-up companies related to photovoltaics per day, and took on board any advice that was offered.

"It was quite unusual to have three Aussies drop in on you in the US back then. We made a huge number of contacts, and those we met didn't mind going out of their way if you wanted some special silicon wafers to make a cell or something. We learned about the latest things that were happening, but also how their labs were set up and how we should be setting up our own; the infrastructure we needed etc." 
Essentially, they used the conference experience to piggyback their broader quest for knowledge and to satisfy three primary objectives: to take in the widest range of information from other sources as possible; to create interest in (and possibly support for) their own work; and to establish working and research partnerships.

"Those opportunities definitely wouldn't have been there if it hadn't been for the conference. People we met on that trip really helped us along. They remembered us afterwards too, and it's been a big part of our history. I'm still in contact with many of these people and even today still work with some of them."

Green and his team returned from the conference inspired. In 1977 they used what they'd learned to develop their own lab and began striving to break what was then known as 'the four minute mile' of photovoltaics: a solar cell efficiency level of 20 per cent. In what seemed to Green to be a race between UNSW and the rest of the world, they quickly leapt ahead, leaving even NASA and COMSAT in their wake. Over the next few years they stayed on top, constantly inching their way towards the 20 per cent target with modifications like reducing the area of contact points between the silicon and the metal, or reducing reflection rates by adding texture to the surface of the cell. In 1985, Green and his team were the first to reach that magical benchmark, and ever since have continued to push the boundaries of the technology, most notably by developing ways to transfer cell efficiency into low-cost production of solar panels. They've broken record after record, as they developed more effective ways of situating and configuring the cells, and in 2014 managed to achieve a remarkable efficiency level of 40 per cent.

By Green's own admission, conferences have played an essential part in this success. As well as the immediate motivational benefits, conferences have been integral to his achievements in terms of providing inspiration and ideas, networks and staffing, and in securing funding for research.

"It's inspiring to meet with like-minded people who are working in the same areas, and it helps to keep everyone interested. There's a real community there that's mainly self-directed, so picking up information quickly I guess is one of the key benefits of conferences." 
Green also believes conferences were helpful in attracting the best new talent for his research teams, admitting he was often approached by postdoctoral students or new graduates interested in his work.

"Conferences were a way for academic supervisors to introduce you to their favourite students and ask whether that student could come out here to do some work. I've personally supervised over 70 research students, and that was quite a natural way of being introduced to someone."

Green has always ensured his staff and students had opportunities to attend conferences to broaden their knowledge base.

"It used to be hard to get funding to attend conferences, so students largely had to pay their own way, but now they can apply for funding through the university so they're attending more often. It's really good for them to be able to make contacts both for their own research they're doing here and for their future career and that's a really important part of their education; conference attendance."

Many of Green's past students have gone on to lead solar technology companies across the globe, particularly in China and throughout Asia. Demand for solar cells began increasing quickly in the early 2000 s, creating the potential for quick expansion, so there was plenty of US financial backing for those start-ups that looked like they knew what they were doing. According to Green, one of the main criteria used to assess a company's viability was "whether they had contact with good technology such as at UNSW, so a lot of those companies appointed Chief Technology Officers that had trained here with us."

"They were mainly students from a Chinese background, but not all, and that means there's literally dozens of companies with past students running them who learnt most [of what] they know about solar here and who see us as a likely source of new knowledge on where they should be heading."

Another important benefit of conferences for Green was the opportunities they gave him to make contacts and establish networks. Along with other leading scientists like Nobel Laureate Professor Brian Schmidt 
(astronomer), Green admits his approach to success is to focus on competing internationally. He says that international links are important to Australia's success and that conferences definitely were the vehicle through which most of those links were forged.

"The networking aspects of conferences are quite important; often more so than what you learned technically.

"You might get to talk to people outside your own area and get an update on areas you're not as familiar with. I find that very useful. Some people I got to know through conferences but at the time I wasn't too interested in what they were doing, but since then our work has become so broad that they're now in our collaborative team."

Another strategy Green employed to ensure he got the most from a conference was to try to present his research as early in the program as possible.

"That's important because then if people are interested in one aspect of your work or another they come up to you throughout the conference and you have more chances of meeting them at the social functions and other networking events."

And whilst conferences were the catalyst for most of his international connections, they also helped him to develop close ties with local people he would otherwise not have sat and talked with.

"Even local people - some working in Melbourne - you don't get a chance to see them very often, but if you're travelling to a conference together and you realise you're both Australian you're more likely to meet up and talk with each other."

An ongoing concern for Green and his team throughout the years, however, was funding. Despite their remarkable record of success, the huge costs involved in maintaining a large research project such as theirs meant they needed to constantly source research grants and financial partnerships. In the early 1980s they realised they needed more funding than could be sourced locally, so they made it an objective to get overseas funding through conferences. 
"The people in charge of giving out funding would cotton onto the idea that we were doing useful work when they saw the presentations we gave at conferences.

"They'd then meet with us to see what could be done in terms of them organising funding and that kind of thing. We received one grant from NASA in the early 1980's that tied us over for a while but between when Reagan was elected and the Chernobyl accident occurred funding got quite tight and we were struggling to maintain the activity levels we'd built up. We got several grants from the US Department of Energy in the late 80's, organised through conferences we went to and the international contacts we'd made at previous conferences, so they were very important."

He also noted that funding support from industry can come about as a result of conferences.

"Some conferences now have very large exhibitions associated with them, particularly in Europe, so there's a good chance to catch up with industry people. There's been a lot of funding from industry organised through conferences over recent years."

Green, whose research centre (the Australian Centre for Advanced Photovoltaics) is now funded by the Australian National Energy Agency (ARENA), says another important aspect with regard to funding was the way links and contacts made through conferences could be used to demonstrate international collaboration, particularly important in terms of success of funding applications in Australia.

"Funding bodies here in Australia seem focussed on encouraging collaboration. There is pressure on you to collaborate and on most funding applications it is the collaboration aspect that attracts the support."

He said that when he applied for funding to establish the centre, he approached the strongest groups in the photovoltaic research area in the country and put in a combined application to demonstrate how they would be collaborating.

"We knew that was a better strategy than each group applying individually, trying to blow each other out of the water." 
And whilst Green is clearly an avid believer in the long-term and significant benefits of conferences, he admits hosting them can be hard work. He and his team hosted the 1989 International Photovoltaic Conference in Sydney, which he says people still mention decades later.

"It was quite demanding on our research group but it created a very favourable impression of Australia in the minds of the people that attended and increased our international standing.

"More people became aware of what we were doing and people have been on at me ever since to organise another one but so far I've shied away. We're so well-known now we don't really need the publicity or exposure, but if we were a smaller group that publicity can be an important benefit from hosting a conference."

Green believes we have great capacity, resources and skills in Australia to host conferences, and people like to come here - but it is challenging to travel from Europe and areas of the US. He believes having good speakers who can convey a lot of information quickly without getting bogged down in detail, plenty of interaction and a well thought out program are three key ingredients of a good conference.

He also sees great benefit, particularly for Australia, in combining conferences with other activities or events, such as the conferences organised by UNSW to coincide with the Sydney Olympics, the European conferences which partner with industry exhibitions, or in wider consultative opportunities/programs such as those he organised for his own trip to the US back in the 70s.

With Australia and its near neighbours in the firing line in terms of the impacts of climate change, Professor Green and his team have made all the right moves to situate Sydney as the photovoltaic technology and educational hub for the Asia-Pacific region. Indeed, there is increasing evidence to suggest it is now technically and economically feasible that our energy systems could run entirely on renewables (water, wind and solar) - 
were the social, political, financial and perceptual barriers to be overcome. And thanks to the knowledge gleaned and the international links forged mainly through conferences, Green and his colleagues have turned Australian 'smarts' into manufacturing realities with the potential to make a significant difference as we work to solve this crucial global problem. 